\title{
Effect of Two Levels of Crude Protein and Methionine Supplementation on Performance of Dairy Cows
}

\author{
C. Leonardi, ${ }^{*}$ M. Stevenson, $†$ and L. E. Armentano* \\ *Department of Dairy Science, University of Wisconsin, Madison 53706 \\ and †Degussa Canada Ltd., Ontario, Canada L7R 3Y8
}

\begin{abstract}
Sixteen Holstein cows in midlactation were randomly assigned to treatments in a replicated $4 \times 4$ Latin square. Two levels of $\mathrm{CP}(16.1 \mathrm{vs} .18 .8 \%)$ with or without supplemental methionine $(0.07 \mathrm{~g} / 100 \mathrm{~g}$ of $\mathrm{DM})$ were tested in a $2 \times 2$ factorial arrangement of treatments. Dry matter intake, milk production, milk composition, and $\mathrm{N}$ excretion were determined. No interactions between CP level and methionine supplementation were observed. Milk production and dry matter intake were not different among treatments. Milk protein concentration increased from 3.17 to $3.26 \%$ with the addition of methionine and decreased from 3.24 to $3.17 \%$ with increased CP. No differences were observed among treatments in milk protein yield. Milk fat concentration was low across all diets, but was increased from $2.33 \%$ with $16.1 \%$ CP diets to $2.68 \%$ with $18.8 \%$ CP diets. No significant treatment effects were observed for SNF, lactose concentration in milk, or casein $\mathrm{N}$ as a fraction of skim milk N. Increased dietary CP increased milk urea $\mathrm{N}$ by $3.9 \mathrm{mg} / \mathrm{dl}$. Methionine supplementation did not affect $\mathrm{N}$ excretion in urine or feces. The higher protein diets increased estimated urine volume by 2.9 $\mathrm{L} / \mathrm{d}$ and increased $\mathrm{N}$ concentration by 1.7 percentage units in both urine and feces. Feeding higher protein increased milk urea and urine $\mathrm{N}$ excretion as expressed as a percentage of total $\mathrm{N}$ excreted ( $44 \mathrm{vs.} 38 \%$ for 18.8 and $16.1 \% \mathrm{CP}$, respectively). Overall, feeding $16.1 \% \mathrm{CP}$ produced milk and milk protein yields similar to feeding $18.8 \% \mathrm{CP}$, but reduced the $\mathrm{N}$ losses in urine and milk urea.
\end{abstract}

(Key words: crude protein, methionine, nitrogen, urine)

Abbreviation key: CLAt10c12 = conjugated linoleic acid trans-10, cis-12, C18:1t10 = C18:1 trans-10 fatty acid, HPC = higher protein control, HPM = higher protein plus methionine, LPC = lower protein control,

Received April 16, 2003.

Accepted August 8, 2003

Corresponding author: L. E. Armentano; e-mail: learment@ facstaff.wisc.edu.
$\mathbf{L P M}=$ lower protein plus methionine, $\mathbf{M D R E}=$ mepron dairy ration evaluator, $\mathbf{M P}=$ metabolizable protein .

\section{INTRODUCTION}

Ammonia volatilization is as an important contributor to soil and surface water eutrophication and acidification (NRC, 2003). Animal farming systems account for approximately $50 \%$ of total $\mathrm{NH}_{3}$ emissions from terrestrial systems into the atmosphere (NRC, 2003). In particular, animal waste accounts for approximately $50 \%$ of all anthropogenic $\mathrm{NH}_{3}$ emissions (NRC, 2003). Dairy cattle secrete roughly 25 to $35 \%$ of the N consumed as milk $\mathrm{N}$, and almost all of the remaining $\mathrm{N}$ is excreted in urine and feces (Chase, 1994). Most urinary $\mathrm{N}$ is excreted as urea (Gonda and Lindberg, 1994; Broderick, 2003) and may be lost as ammonia into the atmosphere (Van Horn et al., 1994). One possible way of reducing urinary $\mathrm{N}$ excretion is by reducing the amount of dietary CP fed to the cow. In fact, decreasing dietary CP from 18.4 to $15.1 \%$ linearly decreased urinary $\mathrm{N}$ expressed as grams per day or as a percentage of $\mathrm{N}$ intake (Broderick, 2003). Unfortunately, dietary CP reduction also decreased milk production by $1.1 \mathrm{~kg} / \mathrm{d}$ (Broderick, 2003) and milk protein yield by nearly 100 g/d (Kalscheur et al., 1999).

Balancing diets for limiting AA could improve production response of lower protein diets without increasing N losses in urine. Dinn et al. (1998) showed that feeding diets with 16.7 or $15.3 \%$ CP supplemented with protected methionine and lysine supported milk and milk protein production as much as feeding $18.3 \% \mathrm{CP}$ without added $\mathrm{AA}$, and reduced $\mathrm{N}$ excretion in urine. The lack of a treatment low in protein without AA limited the possibility of determining whether the results obtained were due to the different protein levels or to the AA supplementation.

Methionine has been shown to be the first-limiting AA for diets containing soy protein as the primary protein supplement (Casper and Schingoethe, 1988). Under the assumption that dairy cattle require a certain amount of duodenal methionine to maximize production, the primary objective of this experiment was to verify the hypothesis that a lower protein diet with 
supplemented methionine would support milk production as much as a higher $\mathrm{CP}$ diet while reducing $\mathrm{N}$ excretion in urine. In an experiment where treatments comprised two levels of CP with or without methionine addition, the hypothesis would be supported by an interaction with supplemental methionine, improving performance and efficiency of the lower CP diet with less effect on the higher $\mathrm{CP}$ diet.

\section{MATERIALS AND METHODS}

\section{Animals}

Twelve multiparous and 4 primiparous Holstein cows were used in a $4 \times 4$ Latin square trial with 35 -d periods. At the beginning of the study, multiparous cows averaged $( \pm \mathrm{SD}) 94 \pm 28 \mathrm{DIM}$ and $47.6 \pm 7.1 \mathrm{~kg} / \mathrm{d}$ of milk production, and primiparous cows averaged $99 \pm 4 \mathrm{DIM}$ and $35.2 \pm 2.1 \mathrm{~kg} / \mathrm{d}$ of milk production. The sequence of treatments was different in each square and was selected to balance for carryover effect. Cows were assigned to each square according to parity and current milk production. Cows were housed in tie stalls or stanchions, with free access to water. Cows were injected with bovine somatotropin (Posilac, Monsanto Co., St. Louis, MO) starting $4 \mathrm{~d}$ prior to the beginning of the first period and on d 8, 20, and 31 of each period. The Research Animal Resource Center of the University of Wisconsin-Madison approved all procedures involving animals. One cow developed chronic mastitis at the beginning of the second period; therefore, all data collected from that cow were deleted from the statistical analysis.

\section{Diets}

Treatments were arranged as a $2 \times 2$ factorial, with two levels of CP (16.1 vs. $18.8 \%$ ) with or without supplemented methionine $(0.07 \mathrm{~g} / 100 \mathrm{~g}$ of DM; Mepron M85, Degussa Hüls Corp., Allendale, NJ). Treatments were lower protein control (LPC), lower protein plus methionine (LPM), higher protein control (HPC), and higher protein plus methionine (HPM). Nutrient requirement and AA flow to the duodenum were estimated according to the Mepron Dairy Ration Evaluator (MDRE) (ver. 2.1, Degussa Hüls Corp.). Diets were balanced for cows that produced $44.5 \mathrm{~kg}$ of milk daily (3.6\% fat and $3.2 \%$ $\mathrm{CP}$ ), ate $24.6 \mathrm{~kg}$ of DM daily, weighed $612 \mathrm{~kg}$, and were 85 DIM. The higher protein level was chosen in order to fulfill RDP, RUP, and lysine requirements. The lower protein level was chosen in order to fulfill lysine requirements. The LPM diet fulfilled methionine and lysine requirements. Urea replaced part of soybean meal in the lower protein diets in order to minimize the likelihood that $\mathrm{NH}_{3}-\mathrm{N}$ would be limiting for microbial growth
(NRC, 2001) and to reduce the discrepancy in RDP between the two dietary CP levels. Mepron M85 contained a minimum of $85 \%$ (by weight) of DL-methionine. Berthiaume et al. (2000) utilized an in situ technique to estimate disappearance of methionine from Mepron M85. The authors reported an average disappearance of $16.1 \%$ in the rumen, $47.8 \%$ postrumen, and $63.9 \%$ in the total tract. Therefore, approximately $64 \%$ of the methionine fed was available to the animal. According to MDRE, duodenal flow of methionine was estimated to be $50 \mathrm{~g} / \mathrm{d}$ for LPC, $62 \mathrm{~g} / \mathrm{d}$ for LPM, $57 \mathrm{~g} / \mathrm{d}$ for HPC, and $67 \mathrm{~g} / \mathrm{d}$ for HPM; the requirement was estimated to be $60 \mathrm{~g} / \mathrm{d}$. Duodenal flow of lysine was estimated to be $180 \mathrm{~g} / \mathrm{d}$ for LPC and LPM, 205 for HPC and HPM, and the requirement was estimated to be $183 \mathrm{~g} / \mathrm{d}$.

This experiment was conducted prior to the NRC (2001) publication, so diets are not balanced according to NRC (2001) requirements. However, diets were subsequently evaluated by the NRC (2001) model, considering cow characteristics previously listed. Duodenal flow of methionine was estimated to be $50 \mathrm{~g} / \mathrm{d}$ for LP and $54 \mathrm{~g} / \mathrm{d}$ for HPC. Duodenal flow of lysine was estimated to be $177 \mathrm{~g} / \mathrm{d}$ for LPC and 201 for HPC. The NRC (2001) did not report any requirement for methionine and lysine expressed as grams per day, but suggested that lysine should constitute $7.2 \%$ of metabolizable protein (MP), and methionine 2.4\% of MP. According to NRC (2001), lysine concentration as a percentage of MP was 6.5 and $6.3 \%$ in the lower and higher protein diets, respectively. Methionine concentration as a percentage of MP was $1.8 \%$ in LP and $1.7 \%$ in HPC. Assuming that methionine availability of Mepron M85 is 64\%, the substitution of 0.08 percentage units (DM basis) of corn grain with Mepron M85 increased methionine concentration as a percentage of MP to 2.2 and $2.1 \%$ for LPM and HPM diets, respectively.

Dietary ingredients and chemical composition (mathematically calculated from individual feedstuff) are shown in Table 1. Diet DM contained approximately $55 \%$ forage, $40 \%$ concentrate, and 5\% cottonseed. Corn silage fed was brown-midrib hybrid (F657, Cargill, Minneapolis, MN; relative maturity at $115 \mathrm{~d}$ ). Corn was harvested at a $1.9 \mathrm{~cm}$ theoretical length of cut, and a processor was not utilized on the harvester (model 860, Gehl, West Bend, WI). Corn silage was stored in a bunker silo before the start of the trial. Three weeks before the silage was fed, it was transferred to a concrete stave silo. Alfalfa was harvested at the early bloom stage of maturity, at a $1.9 \mathrm{~cm}$ theoretical length of cut and stored in a $3.7 \times 12.2 \mathrm{~m}$ concrete stave silo. The concentrates were premixed and designated lower protein or higher protein grain mixes for the lower and higher protein diets, respectively. Part of the corn (2\% of the diet, DM basis) was not included in the mix. This corn was 
Table 1. Ingredients and chemical composition of the diets.

\begin{tabular}{|c|c|c|c|c|}
\hline & \multicolumn{4}{|c|}{ Treatments $^{1}$} \\
\hline & LPC & LPM & $\mathrm{HPC}$ & $\mathrm{HPM}$ \\
\hline Ingredient & \multicolumn{4}{|c|}{$\longrightarrow \mathrm{g} / 100 \mathrm{~g}$ of $\mathrm{DM}$} \\
\hline Alfalfa silage ${ }^{2}$ & 16.2 & 16.2 & 16.2 & 16.2 \\
\hline Corn silage $^{3}$ & 38.6 & 38.6 & 38.6 & 38.6 \\
\hline Cottonseed & 5.7 & 5.7 & 5.7 & 5.7 \\
\hline Ground corn grain & 25.2 & 25.12 & 16.3 & 16.22 \\
\hline Soybean meal $48 \%$ CP & 0 & 0 & 9.5 & 9.5 \\
\hline Mepron M85 ${ }^{4}$ & 0 & 0.08 & 0 & 0.08 \\
\hline Roasted whole soybean ${ }^{5}$ & 8.1 & 8.1 & 8.1 & 8.1 \\
\hline Soy plus ${ }^{6}$ & 2.0 & 2.0 & 2.0 & 2.0 \\
\hline Blood meal & 1.0 & 1.0 & 1.0 & 1.0 \\
\hline Urea & 0.6 & 0.6 & 0 & 0 \\
\hline Tallow & 0.8 & 0.8 & 0.8 & 0.8 \\
\hline Limestone & 0.6 & 0.6 & 0.6 & 0.6 \\
\hline Dicalcium phosphate & 0.6 & 0.6 & 0.6 & 0.6 \\
\hline Trace mineral salt ${ }^{7}$ & 0.4 & 0.4 & 0.4 & 0.4 \\
\hline Vitamins mix ${ }^{8}$ & 0.2 & 0.2 & 0.2 & 0.2 \\
\hline \multicolumn{5}{|l|}{ Chemical composition $^{9}$} \\
\hline DM, g/100 g (as fed) & 55.0 & 55.0 & 55.0 & 55.0 \\
\hline $\mathrm{NE}_{\mathrm{L}}, \mathrm{Mcal} / \mathrm{kg}$ of $\mathrm{DM}^{10}$ & 1.63 & 1.63 & 1.65 & 1.65 \\
\hline CP & 161 & 161 & 8 & \\
\hline $\mathrm{RDP}^{11}$ & $\begin{array}{l}16.1 \\
11.1\end{array}$ & $\begin{array}{l}10.1 \\
11.1\end{array}$ & $\begin{array}{l}18.8 \\
12.3\end{array}$ & $\begin{array}{l}18.9 \\
12.3\end{array}$ \\
\hline RUP $^{12}$ & 5.0 & 5.0 & 6.5 & 6.6 \\
\hline $\mathrm{NDF}$ & 27.0 & 27.0 & 27.4 & 27.4 \\
\hline $\mathrm{ADF}$ & 15.3 & 15.3 & 15.1 & 15.1 \\
\hline $\mathrm{NFC}^{13}$ & 45.7 & 45.7 & 42.3 & 42.3 \\
\hline $\mathrm{FA}^{14}$ & 4.7 & 4.7 & 4.3 & 4.3 \\
\hline $\operatorname{Ash}^{15}$ & 5.5 & 5.5 & 6.2 & 6.2 \\
\hline
\end{tabular}

${ }^{1}$ Treatments: $\mathrm{LPC}=$ lower protein control, $\mathrm{LPM}=$ lower protein plus methionine, $\mathrm{HP}=$ higher protein, $\mathrm{HPM}=$ higher protein plus methionine.

${ }^{2}$ Alfalfa silage contained $43.7 \% \mathrm{DM}, 18.4 \% \mathrm{CP}, 14.2 \% \mathrm{RDP}, 45.1 \%$ $\mathrm{NDF}, 33.0 \% \mathrm{ADF}, 9.1 \%$ ash, and $0.9 \%$ fatty acids on a DM basis.

${ }^{3}$ Corn silage contained $40.7 \% \mathrm{DM}, 7.8 \% \mathrm{CP}, 5.8 \% \mathrm{RDP}, 30.9 \% \mathrm{NDF}$, $14.8 \% \mathrm{ADF}, 4.6 \%$ ash, and $2.3 \%$ fatty acids on a DM basis.

${ }^{4}$ Mepron M85 (Degussa, Hüls Corp., Allendale, NJ) contained a minimum of $85 \%$ by weight of DL-methionine.

${ }^{5}$ Whole soybeans were roasted at temperatures ranging from 143 to $149^{\circ} \mathrm{C}$.

${ }^{6}$ Soy plus, West Central Cooperative, Ralston, IA.

${ }^{7}$ Contained $0.55 \% \mathrm{Mn}, 0.55 \% \mathrm{Zn}, 0.35 \% \mathrm{Fe}, 0.14 \% \mathrm{Cu}, 0.008 \% \mathrm{I}$, $0.006 \%$ Se, and $0.002 \%$ Co.

${ }^{8}$ Contained $3304 \mathrm{IU} / \mathrm{g}$ of vitamin A, $1101 \mathrm{IU} / \mathrm{g}$ of vitamin $\mathrm{D}$, and $11 \mathrm{IU} / \mathrm{g}$ of vitamin $\mathrm{E}$.

${ }^{9}$ Chemical composition was mathematically calculated based on values for individual feedstuffs.

${ }^{10} \mathrm{NE}_{\mathrm{L}}$ values were based on $\mathrm{NRC}$ (2001) values for individual feedstuffs.

${ }^{11}$ The RDP values were based on individual feed analyzed at the beginning of the trial.

${ }^{12} \mathrm{RUP}=\mathrm{CP}-\mathrm{RDP}$.

${ }^{13} \mathrm{NFC}=100-(\mathrm{FA}+1+\mathrm{NDF}+\mathrm{CP}+$ ash $)$.

${ }^{14} \mathrm{FA}=$ fatty acids.

${ }^{15}$ Diets contained $0.8 \%$ of $\mathrm{Ca}$, and $0.45 \%$ of $\mathrm{P}$.

combined with methionine and added daily to the LPM and HPM diets. The same amount of unsupplemented corn was added daily to the LPC and HPC diets. Diets were mixed once daily and fed as a TMR twice daily at 800 and $1700 \mathrm{~h}$ to allow for $10 \%$ feed refusal daily.

\section{Sampling and Analysis}

Diets were adjusted weekly to account for fluctuations in the DM content of the forages. During the last 2 wk of each period, feeds were sampled for further analysis and composited by period. Feed samples were dried at $60^{\circ} \mathrm{C}$ for $48 \mathrm{~h}$, ground to pass through a $1-\mathrm{mm}$ screen (Wiley mill, Arthur H. Thomas, Philadelphia, $\mathrm{PA}$ ), and analyzed for $\mathrm{DM}, \mathrm{CP}, \mathrm{NDF}, \mathrm{ADF}$, ash, and fatty acids. At the end of the experiment, 1 composited sample of each of the following ingredients was analyzed for AA composition in order to determine AA dietary concentration and intake: alfalfa silage, corn silage, cottonseed, higher protein grain mix, lower protein grain mix, corn grain, and corn grain with Mepron M85. Ort samples were collected during the last $5 \mathrm{~d}$ of each period and composited by animal in proportion to the wet weight of orts from each specific day. The composite ort samples were dried at $60^{\circ} \mathrm{C}$ for $48 \mathrm{~h}$ and analyzed for DM and CP. The CP content was determined by micro-Kjeldahl analysis (AOAC, 1990). Neutral detergent fiber was determined using $\alpha$-amylase (Sigma no. A3306: Sigma Chemical Co., St. Louis, MO), sodium sulfite, and corrected for ash concentration according to Van Soest et al. (1991) adapted for an An$\mathrm{kom}^{200}$ fiber analyzer (Ankom Technology, Fairport, NY). Acid detergent fiber was determined using the method described by Goering and Van Soest (1970), adapted for the Ankom ${ }^{200}$ fiber analyzer (Ankom Technology). Fatty acids were determined following the procedure described by Sukhija and Palmquist (1988) and represented the sum of $\mathrm{C}_{14}$ to $\mathrm{C}_{18}$. The NFC component was calculated as $100-(\mathrm{NDF}+$ ether extract $+\mathrm{CP}+$ ash), where ether extract was calculated as fatty acids +1 (NRC, 2001).

For AA analysis, the feed samples were digested with performic acid to stabilize Cys and Met, followed by acid hydrolysis with $6 \mathrm{~N} \mathrm{HCl}$ (AOAC, 2002). Amino acids were quantified by ion-exchange chromatography (Beckman 6300, Palo Alto, CA). Tryptophan and tyrosine were not reported because they are destroyed during the oxidation process.

Cows were milked twice daily, milk production was recorded, and milk was sampled at each milking during the last $5 \mathrm{~d}$ of each period. Milk samples were analyzed (AgSource Milk Analysis Laboratory, Menomonie, WI) for protein, fat, $\mathrm{SNF}$, lactose and urea $\mathrm{N}$ by infrared analysis with a Fossmatic-605 (Foss Electric, Hillerød, Denmark). For determination of casein, additional milk samples (6 per cow) were collected on d 33 to 35 , and pooled by cow according to production. An aliquot of the pooled sample was centrifuged at $2500 \times g$ at $4^{\circ} \mathrm{C}$ 
for 10 min to prepare skim milk. An aliquot of skim milk was used to precipitate casein in borate buffer according to the procedures of Ng-Kwai-Hang and Hayes (1982). Skim milk and the precipitate were analyzed for Kjeldahl N, and precipitate $\mathrm{N}$ was expressed as a percentage of the skim milk $\mathrm{N}$. An aliquot of whole milk was also collected for Kjeldahl $\mathrm{N}$ analysis in order to express skim milk casein $\mathrm{N}$ both as a percentage of skim and whole milk $\mathrm{N}$.

However, after the experiment ended and milk fat depression was evident across all dietary treatments, the whole milk aliquot was analyzed for milk fatty acid profile in order to verify possible correlations between milk fat percentage and milk fatty acid profile. Fatty acid analysis was performed on approximately $80 \mathrm{mg}$ of milk fat, obtained from centrifuging $4 \mathrm{ml}$ of thawed whole milk at $17,800 \times g$ at $8^{\circ} \mathrm{C}$ for $30 \mathrm{~min}$. Sixty-seven percent of milk samples were available for milk fatty acids analysis. The number of samples missing was 6 for LPC, 3 for LPM, 7 for HPC, and 5 for HPM. Lipid extraction and fatty acids transesterification was performed according to the method described by Chouinard et al. (1999). Fatty acid methyl esters were injected to a gas chromatograph (Perkin Elmer Autosystem, Norwalk, CT) equipped with a $100-\mathrm{m}(0.25 \mathrm{~mm}$ i.d.) open tubular fused-silica capillary column wall coated with CP-Sil 88 (Chrompack \#CP7489, Varian Inc., Walnut Creek, CA). Helium was the carrier gas. Total fatty acid profile and trans-octadecenoic acids were identified, running each sample under 2 different conditions. First, a temperature gradient run was performed in order to determine the fatty acid profile $\left(50\right.$ to $190^{\circ} \mathrm{C}$ at $4^{\circ} \mathrm{C} /$ $\mathrm{min})$. Second, an isothermal run $\left(160^{\circ} \mathrm{C}\right)$ was used to separate most trans-octadecenoic fatty acids. Peaks were identified utilizing individual fatty acids from Supelco Inc. (Bellefonte, PA), Sigma Chemical Co., and Matreya Inc. (Pleasant Gap, PA). Response correction factors for each fatty acid methyl ester, utilized to adjust individual areas, were calculated using a standard butter oil (CRM 164, Commission of the European Communities, Community Bureau of Reference, Brussels, Belgium).

Fecal grab samples were taken every $9 \mathrm{~h}$ from d 30 to 33 for a total of 8 samples per cow, per period. From each time point, approximately $50 \mathrm{~g}$ of wet material was composited, dried at $60^{\circ} \mathrm{C}$ for $48 \mathrm{~h}$, ground to pass through a 1-mm screen (Wiley mill, Arthur H. Thomas), and analyzed for acid detergent lignin and N. Diets were physically reconstituted after the trial ended with ground, dry single ingredients in order to reduce possible TMR sampling error. These reconstituted samples were analyzed for acid detergent lignin, which was determined using the method described by Goering and Van Soest (1970), adapted for the Ankom ${ }^{200}$ fiber ana- lyzer. Apparent digestibility was calculated assuming acid detergent lignin was completely resistant to digestion.

Total urine collection was performed during the first period for $24 \mathrm{~h}$ on d 34 using a 24 French balloon foley catheter (C.R. Bard, Inc., Covington, GA), draining into $500 \mathrm{ml}$ of $1.5 \mathrm{~N} \mathrm{H}_{2} \mathrm{SO}_{4}$ in plastic containers. Urine was measured and sampled every $4 \mathrm{~h}$. A composited sample for each cow was used to measure daily creatinine excretion per kilogram of BW. This coefficient for each individual cow was used to predict urine output from period 1 based on creatinine concentration in 3 intermittent samples of urine and BW. Body weight was measured on $\mathrm{d} 32$ and 33 at $800 \mathrm{~h}$ before feeding, and averaged $653 \pm 54 \mathrm{~kg}( \pm \mathrm{SD})$. Urine output (L/d) was calculated as BW $(\mathrm{kg}) \times$ creatinine excretion rate $(\mathrm{mg} / \mathrm{kg}$ of $\mathrm{BW} /$ d) divided by creatinine concentration $(\mathrm{mg} / \mathrm{L})$, as described by Valadares et al. (1999). Using period 1 data, predicted urine output was regressed against actual collected volume. There was no difference between actual and predicted urine volume, and treatment had no effect on the relationship. Therefore, the daily creatinine excretion per kilogram of BW averaged across all cows on 4 treatments $(27.64 \mathrm{mg} / \mathrm{kg}$ of BW/d) was applied to samples from period $1,2,3$, and 4 to predict urine output. Therefore, no total urine collection was done during the second, third, or fourth periods, when spot samples of urine were collected every $6 \mathrm{~h}$ over a $24-\mathrm{h}$ period. Samples were composited by cow and by period and analyzed for $\mathrm{N}$ and creatinine concentration using a commercial kit (Sigma no. 555; Sigma Chemical Co.).

\section{In Sacco Measurements}

Crude protein degradability of concentrate ingredients was determined prior to the beginning of the experiment using 4 lactating cows fitted with ruminal cannulas. The diet fed to the fistulated cows was the same as LPC, except that it contained $20 \%$ ground corn grain and $5.1 \%$ soybean meal in place of the $25.2 \%$ corn and $0 \%$ soybean meal in the LPC diet (DM basis). Duplicate Dacron polyester bags $(9 \times 15 \mathrm{~cm}, 52 \pm 5 \mu \mathrm{m}$ pore size $)$ were incubated in each cow for $0,2,6,12,24,48$, and $72 \mathrm{~h}$ to determine in situ DM and CP disappearance. Bags containing $5 \mathrm{~g}$ (DM basis) of material were soaked in warm water for 5 min prior to incubation, placed in a nylon laundry bag, and inserted in the ventral sac of the rumen. After incubation, bags were immediately rinsed in cold water and washed in a commercial washing machine for 2 cycles of $15 \mathrm{~min}$. The $0 \mathrm{~h}$ bags were not incubated in cows but followed the same washing procedure. Bags were dried in a forced-air oven at $60^{\circ} \mathrm{C}$ for $48 \mathrm{~h}$ to determine DM disappearance. Residues from each cow, for each time point, were composited and analyzed for CP. The 72-h time point did not have 
Table 2. Ruminal crude protein degradability characteristics of grain sources, cottonseed, and blood meal.

\begin{tabular}{|c|c|c|c|c|c|c|c|c|}
\hline \multirow[t]{3}{*}{ Feed component } & \multicolumn{2}{|c|}{$\begin{array}{l}\text { Degradation } \\
\text { Rate, per hour }\end{array}$} & \multicolumn{2}{|c|}{$\begin{array}{c}\text { Slowly } \\
\text { degradable }\end{array}$} & \multicolumn{2}{|c|}{$\begin{array}{l}\text { Resistant } \\
\text { fraction }\end{array}$} & \multicolumn{2}{|c|}{$\begin{array}{c}\text { Predicted } \\
\text { undegraded }\end{array}$} \\
\hline & & & & & Propor & of $\mathrm{CP}$ & & \\
\hline & $\mathrm{X}$ & SD & $\mathrm{X}$ & SD & $\mathrm{X}$ & SD & $\mathrm{X}$ & SD \\
\hline Ground corn grain & 0.062 & 0.015 & 0.530 & 0.010 & 0.020 & 0.010 & 0.256 & 0.025 \\
\hline Soybean meal & 0.083 & 0.017 & 0.768 & 0.037 & 0.025 & 0.037 & 0.356 & 0.027 \\
\hline Roasted whole soybean & 0.047 & 0.005 & 0.881 & 0.013 & 0.010 & 0.013 & 0.467 & 0.020 \\
\hline Soy plus ${ }^{1}$ & 0.044 & 0.006 & 0.732 & 0.020 & 0.027 & 0.020 & 0.419 & 0.018 \\
\hline Cottonseed & 0.157 & 0.028 & 0.696 & 0.009 & 0.090 & 0.009 & 0.261 & 0.022 \\
\hline Blood meal & 0.065 & 0.033 & 0.113 & 0.032 & 0.855 & 0.032 & 0.914 & 0.006 \\
\hline
\end{tabular}

Soy plus, West Central Cooperative, Ralston, IA.

enough material to be analyzed separately for each cow, so residues from all 4 cows were pooled, and only 1 value of $\mathrm{CP}$ was available for each ingredient for that time point. Ruminal CP degradability of grains, cottonseed, and blood meal is reported in Table 2 . Crude protein degradability of alfalfa and corn silages was determined by the Soil and Forage Analysis Laboratory (Marshfield, WI), using a near-infrared reflectance spectrophotometer (model 6500; NIR Systems, Perstop Analytical, Silver Spring, MD).

\section{Statistical Analysis}

Data were analyzed using the mixed procedure of SAS (SAS Inst., Inc., Cary, NC). The final model included square, period, dietary CP level, methionine supplementation, and $\mathrm{CP} \times$ methionine interaction. Cow within square was the term of the random statement. Values reported are least squares means. Significance was declared at $P \leq 0.05$, and a trend was reported if $0.05<P \leq 0.10$.

The kinetics of CP disappearance in sacco was estimated using a nonlinear least squares model (PROC NLIN of SAS; SAS Inst., Inc.). For each cow, the following model (McDonald, 1981) was fitted to the percentage of disappearance:

$$
y=a+b\left[1-e^{-k d(t-L)}\right] \text { for } t>L
$$

where $\mathrm{a}=$ soluble fraction $(\%), \mathrm{b}=$ slowly digestible fraction $(\%), \mathrm{k}_{\mathrm{d}}=$ fractional rate of disappearance $\left(\% \mathrm{~h}^{-1}\right), \mathrm{L}=$ lag time $(\mathrm{h})$, and $\mathrm{t}=$ incubation time $(\mathrm{h})$. The indigestible fraction was calculated by difference.

The relationship between C18:1trans-10 fatty acid (C18:1t10), as a percentage of total milk fatty acids, vs. milk fat percentage was estimated utilizing the mixed procedure of SAS (SAS Inst., Inc.). Cow within square was the term of the random statement. The equation that best fit data was chosen according to the Schwarz Bayesian criterion (SAS Inst., Inc.).

\section{RESULTS AND DISCUSSION}

\section{Diet Composition}

The NDF values of samples of cottonseed and corn silage collected prior to the beginning of the trial to balance the diets were greater than during the trial (data not shown). This difference resulted in a low dietary NDF value in all diets fed (Table 1). All four diets had the same $\mathrm{DM}$ content and similar $\mathrm{NE}_{\mathrm{L}}$ as planned. The CP of LPC and LPM was 3.7 percentage units more degradable compared with HPC and HPM (68.9 vs. $65.2 \%$, derived from Table 1). This was due to a higher degradability of corn protein compared with soybean meal protein (Table 2), and the utilization of urea. All the diets were adequate in $\mathrm{RDP}$ according to the NRC (2001).

The AA profiles of the feeds and diets are reported in Table 3. The lower protein diets were lower in all AA compared with the higher protein diets, except that diets LPM and HPC contained the same quantity of methionine. When diets were formulated with MDRE, diets either fulfilled or were close to fulfilling lysine requirements, but when diets were evaluated in the NRC (2001) program, all diets were found to be deficient in lysine expressed as a percentage of MP. The MDRE estimation of duodenal methionine flow was similar to NRC (2001) estimation for LPC, and was $3 \mathrm{~g} / \mathrm{d}$ higher for HPC. The substitution of $0.07 \%$ (DM basis) of corn grain with methionine increased methionine duodenal flow by $12 \mathrm{~g} / \mathrm{d}$ on the LPM diet and $10 \mathrm{~g} / \mathrm{d}$ on the HPM diet, according to MDRE.

\section{Intake and Lactation Performance}

No interactions between CP levels and methionine supplementation were detected on any of the parameters measured except for milk concentration of C16:0. The lack of an interaction between dietary CP and methionine supplementation does not support the hypothesis that methionine supplementation would increase milk production to a greater extent when cows are fed 
Table 3. Amino acid composition of the feeds and diets.

\begin{tabular}{|c|c|c|c|c|c|c|c|c|c|c|c|c|c|c|}
\hline \multirow[b]{2}{*}{ Feed } & \multicolumn{14}{|c|}{ Amino acids } \\
\hline & Met & Cys & Lys & The & Arg & Iso & Val & Leu & His & Phe & Gly & Ser & Pro & Ala \\
\hline & & & & \multicolumn{8}{|c|}{$\mathrm{g} / 100 \mathrm{~g}$ of $\mathrm{DM}$} & & & \\
\hline Alfalfa silage & 0.26 & 0.14 & 0.75 & 0.69 & 0.38 & 0.74 & 1.13 & 0.99 & 0.28 & 0.70 & 0.80 & 0.69 & 1.08 & 0.99 \\
\hline Corn & 0.12 & 0.15 & 0.18 & 0.27 & 0.23 & 0.25 & 0.69 & 0.39 & 0.15 & 0.30 & 0.33 & 0.32 & 0.54 & 0.53 \\
\hline Cottonsee & 0.36 & 0.38 & 0.87 & 0.69 & 2.12 & 0.56 & 1.17 & 0.84 & 0.55 & 0.99 & 0.83 & 1.00 & 0.78 & 0.83 \\
\hline $\mathrm{HP}^{1}$ grain mix & 0.47 & 0.49 & 1.76 & 1.26 & 2.01 & 1.28 & 2.69 & 1.52 & 0.86 & 1.62 & 1.35 & 1.68 & 1.78 & 1.55 \\
\hline $\mathrm{LP}^{1}$ grain mix & 0.29 & 0.33 & 1.03 & 0.79 & 1.14 & 0.70 & 1.85 & 0.96 & 0.58 & 1.03 & 0.85 & 1.07 & 1.27 & 1.10 \\
\hline Corn & 0.21 & 0.20 & 0.27 & 0.31 & 0.40 & 0.27 & 0.96 & 0.38 & 0.26 & 0.29 & 0.34 & 0.44 & 0.78 & 0.5 \\
\hline Corn $+\mathrm{n}$ & 4.72 & 0.20 & 0.28 & 0.33 & 0.39 & 0.28 & 0.98 & 0.43 & 0.12 & 0.04 & 0.34 & 0.45 & 0.80 & 0.6 \\
\hline Diet & & & & & & & & & & & & & & \\
\hline LPC & 22 & 0.23 & 0.64 & 0.56 & 0.71 & 0.52 & 1.23 & 0.73 & 0.36 & 0.68 & 0.63 & 0.71 & 0.92 & 0.8 \\
\hline LPM & 0.29 & 0.23 & 0.64 & 0.56 & 0.71 & 0.52 & 1.23 & 0.73 & 0.36 & 0.68 & 0.63 & 0.71 & 0.92 & 0.8 \\
\hline HPC & 0.29 & 0.29 & 0.91 & 0.74 & 1.04 & 0.74 & 1.55 & 0.94 & 0.46 & 0.90 & 0.82 & 0.94 & 1.12 & 1.01 \\
\hline HPM & 0.36 & 0.29 & 0.91 & 0.74 & 1.04 & 0.74 & 1.55 & 0.94 & 0.46 & 0.90 & 0.82 & 0.94 & 1.12 & 1.01 \\
\hline
\end{tabular}

${ }^{1} \mathrm{HP}$ grain mix $=$ higher protein grain mix, LP grain mix = lower protein grain mix.

${ }^{2}$ Mepron, Degussa, Hüls Corp. (Allendale, NJ).

${ }^{3}$ Diet: $\mathrm{LPC}=$ lower protein control, LPM = lower protein plus methionine, HPC = higher protein control, HPM = higher protein plus methionine, dietary AA profile was mathematically calculated based on values for individual feedstuff or mixes.

Table 4. Effect of crude protein level and methionine supplementation on dry matter, crude protein, and amino acids intake.

\begin{tabular}{|c|c|c|c|c|c|c|c|c|}
\hline \multirow[b]{2}{*}{ Intake } & \multicolumn{4}{|c|}{ Treatments $^{1}$} & \multirow[b]{2}{*}{ SEM } & \multicolumn{3}{|c|}{ Effect $^{2}(P$-value $)$} \\
\hline & LPC & LPM & HPC & HPM & & $\mathrm{CP}$ & Met & $\mathrm{CP} \times \mathrm{Met}$ \\
\hline $\mathrm{DM}, \mathrm{kg} / \mathrm{d}$ & 22.3 & 21.8 & 22.1 & 23.3 & 0.8 & 0.21 & 0.49 & 0.11 \\
\hline $\mathrm{CP}, \mathrm{kg} / \mathrm{d}$ & 3.5 & 3.6 & 4.2 & 4.5 & 0.1 & $<0.0001$ & 0.41 & 0.12 \\
\hline Methionine, $\mathrm{g} / \mathrm{d}$ & 49.1 & 63.3 & 64.0 & 83.7 & 2.5 & $<0.0001$ & $<0.0001$ & 0.11 \\
\hline Lysine, $g / d$ & 143 & 139 & 201 & 211 & 7 & $<0.0001$ & 0.45 & 0.12 \\
\hline
\end{tabular}

${ }^{1}$ Treatments: $\mathrm{LPC}=$ lower protein control, $\mathrm{LPM}=$ lower protein plus methionine, HPC = higher protein control, HPM = higher protein plus methionine.

${ }^{2} \mathrm{CP}=$ main effect of $\mathrm{CP}$; Met $=$ main effect of methionine; $\mathrm{CP} \times \mathrm{Met}=\mathrm{CP} \times$ methionine interaction.

Table 5. Effect of crude protein level and methionine supplementation on milk yield and milk composition.

\begin{tabular}{|c|c|c|c|c|c|c|c|c|}
\hline & \multicolumn{4}{|c|}{ Treatments $^{1}$} & SEM & \multicolumn{3}{|c|}{ Effect $^{2}(P$-value $)$} \\
\hline Milk yield, $\mathrm{kg} / \mathrm{d}$ & 42.7 & 41.0 & 42.2 & 42.8 & 1.6 & 0.51 & 0.63 & 0.29 \\
\hline Protein & 3.21 & 3.28 & 3.13 & 3.23 & 0.08 & 0.01 & $<0.01$ & 0.55 \\
\hline Fat & 2.27 & 2.39 & 2.71 & 2.65 & 0.12 & $<0.001$ & 0.74 & 0.32 \\
\hline Lactose & 4.67 & 4.64 & 4.67 & 4.67 & 0.06 & 0.63 & 0.35 & 0.46 \\
\hline SNF & 8.69 & 8.74 & 8.60 & 8.67 & 0.13 & 0.08 & 0.20 & 0.72 \\
\hline \multicolumn{9}{|l|}{ Milk component yield, g/d } \\
\hline Protein & 1361 & 1330 & 1311 & 1373 & 45 & 0.93 & 0.71 & 0.26 \\
\hline Fat & 949 & 958 & 1099 & 1116 & 59 & $<0.001$ & 0.69 & 0.91 \\
\hline Lactose & 1980 & 1894 & 1957 & 1981 & 76 & 0.54 & 0.55 & 0.29 \\
\hline SNF & 3686 & 3552 & 3599 & 3686 & 127 & 0.82 & 0.82 & 0.29 \\
\hline MUN & 4.44 & 4.29 & 5.96 & 6.10 & 0.5 & $<0.0001$ & 0.98 & 0.56 \\
\hline
\end{tabular}

${ }^{1}$ Treatments: $\mathrm{LPC}=$ lower protein control, LPM $=$ lower protein plus methionine, HPC $=$ higher protein control, HPM $=$ higher protein plus methionine.

${ }^{2} \mathrm{CP}=$ main effect of $\mathrm{CP}$; Met $=$ main effect of methionine; $\mathrm{CP} \times \mathrm{Met}=\mathrm{CP} \times$ methionine interaction. 
Table 6. Effect of crude protein level and methionine supplementation on milk fatty acid composition.

\begin{tabular}{|c|c|c|c|c|c|c|c|c|}
\hline \multirow[b]{2}{*}{ Profile } & \multicolumn{4}{|c|}{ Treatments $^{1}$} & \multirow[b]{2}{*}{ SEM } & \multicolumn{3}{|c|}{ Effect $^{2}(P$-value $)$} \\
\hline & LPC & LPM & HPC & HPM & & $\mathrm{CP}$ & Met & $\mathrm{CP} \times \mathrm{Met}$ \\
\hline & \multicolumn{4}{|c|}{$\mathrm{g} / 100 \mathrm{~g}$ of fatty acids } & & & & \\
\hline $\mathrm{C} 4$ to $\mathrm{C} 13^{3}$ & 11.0 & 11.6 & 13.0 & 11.9 & 0.8 & 0.06 & 0.64 & 0.16 \\
\hline $\mathrm{C} 14: 0$ & 8.95 & 9.43 & 9.33 & 9.56 & 0.40 & 0.29 & 0.15 & 0.58 \\
\hline C14:1 & 1.06 & 1.13 & 0.96 & 1.11 & 0.11 & 0.23 & 0.05 & 0.45 \\
\hline C16:0 & 24.2 & 25.4 & 26.1 & 25.0 & 0.7 & 0.06 & 0.79 & 0.007 \\
\hline C16:1 & 1.56 & 1.72 & 1.41 & 1.56 & 0.14 & 0.04 & 0.05 & 0.97 \\
\hline $\mathrm{C} 16: 2 \mathrm{n} 4$ & 0.007 & 0.015 & 0.023 & 0.007 & 0.009 & 0.57 & 0.57 & 0.08 \\
\hline $\mathrm{C} 18: 0$ & 8.53 & 7.96 & 8.45 & 8.58 & 0.77 & 0.65 & 0.71 & 0.55 \\
\hline $\mathrm{C} 15+\mathrm{C} 17+\mathrm{C} 19^{4}$ & 1.82 & 1.96 & 1.76 & 2.09 & 0.14 & 0.61 & 0.04 & 0.41 \\
\hline \multicolumn{9}{|l|}{$\mathrm{C} 18: 1$ isomers } \\
\hline trans -4 & 0.05 & 0.07 & 0.04 & 0.03 & 0.02 & 0.27 & 0.70 & 0.46 \\
\hline trans -5 & 0.05 & 0.04 & 0.04 & 0.03 & 0.02 & 0.44 & 0.68 & 0.91 \\
\hline trans $-6+$ trans -8 & 0.71 & 0.59 & 0.48 & 0.51 & 0.09 & 0.05 & 0.53 & 0.32 \\
\hline trans -9 & 0.65 & 0.48 & 0.41 & 0.44 & 0.07 & 0.01 & 0.16 & 0.06 \\
\hline trans -10 & 3.68 & 3.07 & 1.30 & 1.91 & 0.64 & 0.0009 & 0.99 & 0.20 \\
\hline trans -11 & 1.36 & 1.19 & 1.39 & 1.23 & 0.16 & 0.74 & 0.14 & 0.98 \\
\hline trans -12 & 0.95 & 0.72 & 0.67 & 0.75 & 0.07 & 0.02 & 0.15 & 0.006 \\
\hline Total C18:1 trans isomers ${ }^{5}$ & 7.42 & 6.14 & 4.30 & 4.89 & 0.73 & 0.0005 & 0.53 & 0.09 \\
\hline cis $-9^{6}$ & 18.54 & 18.99 & 19.33 & 19.60 & 0.98 & 0.32 & 0.62 & 0.90 \\
\hline$c i s-11$ & 0.31 & 0.35 & 0.42 & 0.35 & 0.05 & 0.16 & 0.72 & 0.19 \\
\hline cis-12 & 0.81 & 0.83 & 0.64 & 0.69 & 0.06 & 0.001 & 0.50 & 0.65 \\
\hline$c i s-13$ & 0.61 & 0.55 & 0.58 & 0.54 & 0.06 & 0.57 & 0.24 & 0.72 \\
\hline cis $-14+$ trans -16 & 0.05 & 0.05 & 0.02 & 0.09 & 0.03 & 0.57 & 0.10 & 0.10 \\
\hline cis-15 & 0.33 & 0.28 & 0.39 & 0.36 & 0.06 & 0.13 & 0.35 & 0.91 \\
\hline CLA $^{7}$ cis -9 trans -11 & 0.78 & 0.75 & 0.80 & 0.77 & 0.09 & 0.82 & 0.68 & 0.97 \\
\hline CLA trans -10 cis- 12 & 0.020 & 0.030 & 0.005 & 0.015 & 0.009 & 0.06 & 0.20 & 0.97 \\
\hline $\mathrm{C} 18: 2$ & 7.22 & 7.20 & 6.93 & 7.17 & 0.39 & 0.56 & 0.70 & 0.64 \\
\hline $\mathrm{C} 18: 3$ & 0.54 & 0.52 & 0.55 & 0.55 & 0.02 & 0.25 & 0.53 & 0.72 \\
\hline Others $^{8}$ & 0.814 & 0.787 & 0.790 & 0.842 & 0.087 & 0.77 & 0.81 & 0.44 \\
\hline Unidentified peaks & 5.48 & 4.32 & 4.25 & 4.25 & 0.45 & 0.07 & 0.12 & 0.11 \\
\hline
\end{tabular}

\footnotetext{
${ }^{1}$ Treatments: $\mathrm{LPC}=$ lower protein control, LPM = lower protein plus methionine, HPC = higher protein control, HPM = higher protein plus methionine.

${ }^{2} \mathrm{CP}=$ main effect of $\mathrm{CP}$; Met $=$ main effect of methionine; $\mathrm{CP} \times \mathrm{Met}=\mathrm{CP} \times$ methionine interaction.

${ }^{3} \mathrm{C} 4$ to $\mathrm{C} 13$ = sum of $\mathrm{C} 4: 0, \mathrm{C} 5: 0, \mathrm{C} 6: 0, \mathrm{C} 7: 0, \mathrm{C} 8: 0, \mathrm{C} 10: 0, \mathrm{C} 11: 0, \mathrm{C} 12: 0$, and $\mathrm{C} 13: 0$.

${ }^{4} \mathrm{C} 15+\mathrm{C} 17+\mathrm{C} 19=$ sum of $\mathrm{C} 15: 0, \mathrm{C} 15: 1, \mathrm{C} 17: 0, \mathrm{C} 17: 1$, and $\mathrm{C} 19: 0$.

${ }^{5}$ Total C18:1 trans isomers = sum of C18:1trans-4, trans -5 , trans-6, trans-8, trans-9, trans-10, trans-11, and trans-12.

${ }^{6}$ The $c i s-9$ peak includes also cis-6,trans-13, trans-14, and trans-15 C18:1 isomers.

${ }^{7} \mathrm{CLA}=$ conjugated linoleic acid.

${ }^{8}$ Others = sum of C20:0, C20:1, C20:2n-6, C20:3n-6, C20:3n-3, C20:4n-6, C20:5n-3, C21:0, C22:0, C22:1n-9, C22:2, C22:6n-3, C23:0, C24:0, and C24:1.
}

a lower CP diet deficient in methionine compared with a diet with higher $\mathrm{CP}$ concentration. Instead, it supports the NRC (2001) approach of expressing AA requirements as a percentage of MP. Expressing methionine requirements as a percentage of MP implies that supplementing methionine at different $\mathrm{CP}$ levels should result in a similar response and no interaction between dietary protein level and methionine supplementation should occur.

No differences in DMI were detected among treatments (Table 4). Greater intake of methionine and lysine, expressed as grams per day, was observed for the higher protein diets. The LPM and HPC diets resulted in approximately the same daily intakes of methionine.

Milk yield (Table 5) did not differ among treatments. The literature has reports of inconsistent results of the effect of methionine supplementation on milk yield. Yang et al. (1986), in a lactation trial, reported a decrease in milk yield when supplementing $15 \mathrm{~g} / \mathrm{d}$ of methionine to a diet containing $15.1 \% \mathrm{CP}$. Another trial with the same design, amount of methionine added, and similar dietary CP, but with soybean meal instead of heat-treated soybean meal, showed an increase in milk yield (Illg et al., 1987). No increase in milk yield was observed when dietary CP was either 15.7 or $16.2 \%$ and $17 \mathrm{~g} / \mathrm{d}$ of methionine was supplemented (Overton et al., 1998), or when dietary CP was $19.5 \%$ and 10.5 $\mathrm{g} / \mathrm{d}$ of methionine was supplemented (Armentano et. al., 1997). No differences across treatments were detected in percentage or yield of lactose and SNF, and casein $\mathrm{N}$ expressed as fraction of skim milk $\mathrm{N}$ (Table 5). Similarly, Armentano et al. (1997) reported no effect 


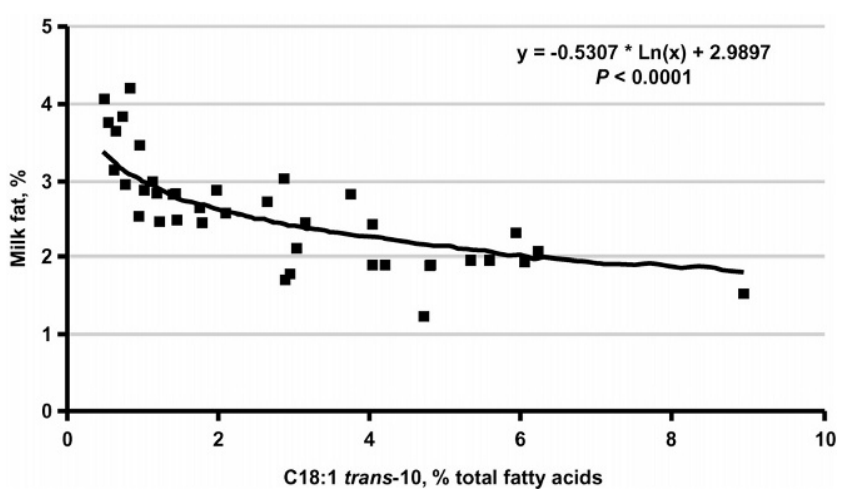

Figure 1. Relationship between C18:1trans-10 as a percentage of total milk fatty acids vs. milk fat percentage. Each point represents data from an individual cow within a period. Sixty-seven percent of the data points were available for analysis. The value for $\mathrm{y}$ at $\mathrm{x}=1$ differed $(P<0.0001)$ from zero. The SE was 0.07 for slope and 0.12 for intercept.

of methionine addition on casein $\mathrm{N}$ expressed as a fraction of skim milk $\mathrm{N}$.

Milk protein percentage increased with the addition of methionine (3.17 vs. $3.26 \%$ ) and decreased with increased CP content in the diet (3.24 vs. $3.18 \%)$. Milk protein yield was not significantly different among treatments. Some trials, in which additional methionine was supplied, had increased milk protein percentage (Schingoethe et al., 1988; Armentano et al. 1997), but this did not always result in a significant increase in protein yield (Schingoethe et al., 1988). Other trials did not show a response in protein percentage or yield with the addition of methionine (Munneke et al. 1991; Polan et al., 1991; Overton et al., 1998).

Low milk fat was evident among all treatments (Table 5). A significant increase in percentage (2.68 vs. $2.33 \%$ ) and fat yield (1108 vs. $954 \mathrm{~g}$ ) was observed when feeding $18.9 \%$ CP compared with $16.1 \%$ CP. Different experiments tested the effect of various levels of dietary CP (ranging from 13.7 to $23.8 \% \mathrm{DM}$ ) on milk fat (Jaquette et al., 1987, 1988; Zimmerman et al., 1991, 1992a,b). The treatments were tested on primiparous and multiparous cows during early and midlactation, with high- and low-fiber diets. In 2 articles (Jaquette et al., 1987; Zimmerman et al., 1992a) out of 5 surveyed, no effect of $\mathrm{CP}$ was found on milk fat. In the remaining 3 papers, the authors found a positive effect of CP level on milk fat only when primiparous cows in early lactation were fed a high-fiber diet (Jaquette et al., 1988, Zimmerman et al., 1991, 1992b). No effects were found either on multiparous cows or cows in mid-lactation or on low-fiber diets. The present experiment was conducted on primiparous $(\mathrm{n}=4)$ and multiparous $(\mathrm{n}=12)$ cows, fed a low-fiber diet during mid lactation. Therefore, none of the conditions associated with increased dietary CP increasing milk fat percentage in previous experiments (Jaquette et al., 1988, Zimmerman et al., 1991, 1992b), are present here. The NRC (2001) also summarized 2 theories regarding the ability of CP to increase milk fat and both theories rely on increased methionine availability. However, in the present study, no methionine effect was observed on milk fat percentage or yield. Therefore, the increase in milk fat content due to increased dietary protein cannot be explained solely by increasing available methionine.

Fatty acid profile of milk fat is reported in Table 6. Milk fatty acid characterization was decided after the experiment ended, and although it was not the primary objective of the experiment, it helped to interpret the low milk fat tests. A 1.8-percentage-unit decrease in dietary protein tended to decrease C16:0 (CLAt10c12, $P=0.06$ ), and increase conjugated linoleic acid trans10,cis-12 $(P=0.06)$. Reducing dietary CP from 18.9 to $16.1 \%$ increased total C18:1trans isomers $(P=0.0005)$ in milk fat, mainly because of c18:1t10, which increased from 1.61 to $3.38 \mathrm{~g} / 100 \mathrm{~g}$ of fatty acids $(P=0.0009)$. Feeding a TMR containing $15 \%$ NDF plus corn oil vs. $32.1 \%$ NDF plus saturated fat decreased milk fat percentage from 3.58 to $2.49 \%$ and increased C18:1t10 from 0.33 to $2.9 \mathrm{~g} / 100 \mathrm{~g}$ of fatty acids (Griinari et al., 1998). Although we fed diets with a higher dietary NDF level

Table 7. Effect of crude protein level and methionine supplementation on urinary and fecal parameters.

\begin{tabular}{|c|c|c|c|c|c|c|c|c|}
\hline \multirow[b]{2}{*}{ Item } & \multicolumn{4}{|c|}{ Treatments $^{1}$} & \multirow[b]{2}{*}{ SEM } & \multicolumn{3}{|c|}{$\operatorname{Effect}^{2}(P$-value $)$} \\
\hline & LPC & LPM & HPC & HPM & & $\mathrm{CP}$ & Met & $\mathrm{CP} \times \mathrm{Met}$ \\
\hline \multicolumn{9}{|l|}{ Urine } \\
\hline Creatinine, mg/dl & 96.6 & 95.2 & 81.9 & 81.1 & 6.5 & 0.03 & 0.86 & 0.96 \\
\hline Urine, $\mathrm{L} / \mathrm{d}^{3}$ & 21.6 & 22.0 & 24.3 & 24.9 & 1.5 & 0.06 & 0.75 & 0.94 \\
\hline $\mathrm{N}, \mathrm{g} / \mathrm{L}$ & 9.5 & 9.2 & 11.1 & 10.5 & 0.4 & $<0.01$ & 0.19 & 0.62 \\
\hline Fecal N, g/kg DM & 27.5 & 27.9 & 29.6 & 29.1 & 0.4 & $<0.0001$ & 0.96 & 0.17 \\
\hline
\end{tabular}

\footnotetext{
${ }^{1}$ Treatments: $\mathrm{LPC}=$ lower protein control, LPM = lower protein plus methionine, HPC = higher protein control, HPM = higher protein plus methionine.

${ }^{2} \mathrm{CP}=$ main effect of $\mathrm{CP}$; Met = main effect of methionine; $\mathrm{CP} \times \mathrm{Met}=\mathrm{CP} \times$ methionine interaction.

${ }^{3}$ Estimated based on daily creatinine excretion of $27.64 \mathrm{mg} / \mathrm{kg}$ of BW.
} 
Table 8. Effect of crude protein level and methionine supplementation on nitrogen balance.

\begin{tabular}{|c|c|c|c|c|c|c|c|c|}
\hline \multirow[b]{2}{*}{ Item } & \multicolumn{4}{|c|}{ Treatments $^{1}$} & \multirow[b]{2}{*}{ SEM } & \multicolumn{3}{|c|}{ Effect $^{2}(P$-value $)$} \\
\hline & LPC & LPM & HPC & HPM & & $\mathrm{CP}$ & Met & $\mathrm{CP} \times \mathrm{Met}$ \\
\hline & $\ldots$ & 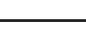 & $\longrightarrow$ & 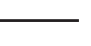 & & & & \\
\hline Intake & 579 & 567 & 678 & 714 & 23 & $<0.0001$ & 0.41 & 0.12 \\
\hline Feces & 120 & 119 & 122 & 135 & 7 & 0.11 & 0.29 & 0.23 \\
\hline Urine & 206 & 201 & 264 & 257 & 16 & $<0.01$ & 0.72 & 0.93 \\
\hline Milk & 213 & 209 & 206 & 215 & 7 & 0.92 & 0.72 & 0.28 \\
\hline Retained & 40 & 38 & 86 & 106 & 22 & $<0.01$ & 0.60 & 0.53 \\
\hline
\end{tabular}

and higher forage content than the low-NDF diets fed by Griinari et al. (1998), milk fat percentage and c18:1t10 concentration were similar. Furthermore, other factors, such as forage source and particle size, could affect milk fatty acid profile. For example, Onetti et al. (2001) showed that replacing alfalfa silage with corn silage in tallow-supplemented diets increased C18:1t10 content in milk, which was associated with a decrease in milk fat percentage. We evaluated the relationship between milk fat percentage and C18:1t10 alone and with CLAt10c12 across treatments. The concentration of CLAt10c12 was not related to milk fat percentage $(P>0.25)$ when $\mathrm{C} 18: 1 \mathrm{t} 10$ was also present in the model. Linear, quadratic, and logarithmic effects of C18:1t10 on milk fat percentage were tested. According to Schwarz's Bayesian criterion, the model that best fit the data was (Figure 1):

$$
\text { milk fat } \%=2.99-0.53 \times \ln (\mathrm{C} 18: 1 \mathrm{t} 10)(P<0.0001)
$$

In this experiment, the difference in composition between lower protein and higher protein diets was a consequence of replacing corn grain with soybean meal; in particular, CP replaced NFC. Although we refer to these as protein effects, clearly the nature of dietary carbohydrate also changed with this substitution. Soybean meal also has a lower fat content and lower linoleic acid content than corn grain. Therefore, it is possible that differences in milk fat due to dietary protein level were actually due to differences unrelated to protein per se.

Increasing dietary protein content by 2.7 percentage units significantly increased MUN by $3.8 \mathrm{mg} / \mathrm{dl}$ and $1.67 \mathrm{~g} / \mathrm{d}$. Similar results were reported by Bach et al. (2000), who found an increase of $6.5 \mathrm{mg} / \mathrm{dl}$ of milk urea $\mathrm{N}$ when dietary protein increased by 3.2 percentage units.

\section{Urinary and Fecal Output}

Methionine supplementation had no effect on either urine volume or urinary $\mathrm{N}$ excretion (Table 7). When
CP level was increased from 16.1 to $18.9 \%$, urine output increased from 21.8 to $24.6 \mathrm{~L} / \mathrm{d}$. Dinn et al. (1998) measured urine output through total collection and reported that urine output increased approximately $2 \mathrm{~L} / \mathrm{d}$ for every 1 percentage unit increment in dietary protein.

Higher concentrations of $\mathrm{N}$ (Table 7) were found in both urine (10.8 vs. $9.3 \mathrm{mg} / \mathrm{dl}$ ) and feces ( 29.3 vs. 27.8 $\mathrm{g} / \mathrm{kg}$ of DM) when feeding 18.9 vs. $16.1 \% \mathrm{CP}$. The increment of urine volume and $\mathrm{N}$ concentration in the urine resulted in a significant increase of $57 \mathrm{~g} / \mathrm{d}$ of urinary $\mathrm{N}$ output (Table 8), but the fecal $\mathrm{N}$ output was not changed (Table 8). The increase of urine $\mathrm{N}$ agrees with the results of Dinn et al. (1998) and Cressmann et al. (1980). They reported an increment of approximately $70 \mathrm{~g} / \mathrm{d}$ of urinary $\mathrm{N}$ when increasing dietary protein by 1.6 or 2.6 percentage units, respectively. Feeding the higher protein diets resulted in a conversion of dietary protein into milk protein of $30.3 \%$ vs. $37.1 \%$ for the lower protein diets. For the higher CP diets, $44 \%$ of the N excreted was excreted as urine and milk urea compared with $38 \%(P<0.01)$ with the lower protein diets.

\section{CONCLUSIONS}

No interactions between CP levels and methionine supplementation were detected on any of the parameters measured except for milk concentration of C16:0. These findings reject the hypothesis that lowering dietary CP increased the need for methionine supplementation; instead, these results support the NRC (2001) system of expressing AA requirements as a percentage of MP. No differences were detected with feeding 16.1 vs. $18.8 \% \mathrm{CP}$ on milk production and milk protein yield. Results suggest that the lower protein diets reduced N losses, thus increasing efficiency in protein utilization and maintaining the same milk production and protein yield of the higher CP diets.

Methionine addition increased milk protein percentage at both dietary protein levels without affecting milk protein yield. Therefore, supplementing methionine in 
soybean-based diet resulted in an increase in milk protein percentage independent from CP level.

\section{ACKNOWLEDGMENTS}

The authors are grateful to the graduate students of the Dairy Nutrition Laboratory for their help in collecting urine samples, to F. Giannico for his help during casein analysis, to S. Bertics for her help in milk fatty acid analysis, and to Degussa Hüls Corp. for their financial support.

\section{REFERENCES}

Armentano, L. E., S. J. Bertics, and G. A. Ducharme. 1997. Response of lactating cows to methionine or methionine plus lysine added to high protein diets based on alfalfa and heated soybeans. J. Dairy Sci. 80:1194-1199.

AOAC. 1990. Official Methods of Analysis. Vol. I. 15th ed. Assoc. Offic. Anal. Chem., Arlington, VA.

AOAC. 2002. Official Methods of Analysis. Vol. I. 17th. Assoc. Offic. Anal. Chem., Arlington, VA.

Bach, A., G. B. Huntington, S. Calsamiglia, and M. D. Stern. 2000. Nitrogen metabolism of early lactation cows fed diets with two different levels of protein and different amino acid profiles. J. Dairy Sci. 83:2585-2595.

Berthiaume, R., H. Lapierre, M. Stevenson, N. Coté, and B. W. McBride. 2000. Comparison of the in situ and in vivo intestinal disappearance of ruminally protected methionine. J. Dairy Sci. 83:2049-2056.

Broderick, G. A. 2003. Effects of varying dietary protein and energy levels on the production of lactating dairy cows. J. Dairy Sci. 86:1370-1381.

Casper, D. P., and D. J. Schingoethe. 1988. Protected methionine supplementation to a barley-based diet for cows during early lactation. J. Dairy Sci. 71:164-172.

Chase, L. E. 1994. Environmental considerations in developing dairy rations. Pages 56-62 in Proc. Cornell Nutr. Conf. Feed Manuf., Rochester, NY. Cornell Univ., Ithaca, NY.

Chouinard, P.Y., L. Corneau, D. M. Barbano, L. E. Metzger, and D. E. Bauman. 1999. Conjugated linoleic acids alter milk fatty acid composition and inhibit milk fat secretion in dairy cows. J. Nutr. 129:1579-1584.

Cressman, S. G., D. G. Grieve, G. K. Macleod, E. E. Wheeler, and L. G. Young. 1980. Influence of dietary protein concentration on milk production of dairy cattle in early lactation. J. Dairy Sci. 63:1839-1847.

Dinn, N. E., J. A. Shelford, and L. J. Fisher. 1998. Use of the Cornell net carbohydrate and protein system and rumen-protected lysine and methionine to reduce nitrogen excretion from lactating dairy cows. J. Dairy Sci. 81:229-237.

Goering, H. K., and P. J. Van Soest. 1970. Forage Fiber Analysis (Apparatus, Reagents, Procedures, and some Applications). Agric. Handbook No. 379. ARS-USDA, Washington, DC.

Griinari, J. M., D. A. Dwyer, M. A. McGuire, D. E. Bauman, D. L. Palmquist, and K. V. V. Nurmela. 1998. Trans-octadecenoic acids and milk fat depression in lactating dairy cows. J. Dairy Sci. 81:1251-1261.

Gonda, H. L., and J. E. Lindberg. 1994. Evaluation of dietary nitrogen utilization in dairy cows based on urea concentrations in blood, urine and milk, and on urinary concentration of purine derivatives. Acta Agric. Scand., Sect. A., Anim. Sci. 44:236-245.

Kalscheur, K. F., J. H. Vandersall, R. A. Erdman, R. A. Kohn, and E. Russek-Cohen. 1999. Effects of dietary crude protein concentration and degradability on milk production responses of early, mid, and late lactation dairy cows. J. Dairy Sci. 82:545-554.
Illg, D. J., J. L. Sommerfeldt, and D. J. Schingoethe. 1987. Lactational and systemic responses to the supplementation of protected methionine in soybean meal diets. J. Dairy Sci. 70:620-629.

Jaquette, R. D., A. H. Rakes, and W. J. Croom, Jr. 1987. Effect of amount and source of dietary nitrogen on milk fat depression in early lactation dairy cows. J. Dairy Sci. 70:1202-1210.

Jaquette, R. D., A. H. Rakes, and W. J. Croom, Jr. 1988. Effect of body condition and protein on milk fat depression in early lactation dairy cows. J. Dairy Sci. 71:2123-2134.

McDonald, I. 1981. A revised model for estimation of protein degradability in the rumen. J. Agric. Sci. 96:251-252.

Munneke, R. L., D. J. Schingoethe, and D. P. Casper. 1991. Lactational evaluation of ruminally protected methionine in diets containing extruded soybeans and urea. J. Dairy Sci. 74:227-233.

NRC. 2001. Nutrient Requirements of Dairy Cattle. 7th rev. ed. Natl. Acad. Sci., Washington, DC.

NRC. 2003. Air Emissions from Animal Feeding Operations: Current Knowledge, Future Needs. Natl. Acad. Sci., Washington, DC.

Ng-Kwai-Hang, K. F., and J. F. Hayes. 1982. Effects of potassium dichromate and sample storage time on fat and protein by MilkoScan and on protein and casein by a modified Pro-Milk MkII method. J. Dairy Sci. 65:1895-1899.

Onetti S. G., R. D. Shaver, M. A. McGuire, and R. R. Grummer. 2001. Effect of type and level of dietary fat on rumen fermentation and performance of dairy cows fed corn silage-based diets. J. Dairy Sci. 84:2751-2759.

Overton, T. R., L. S. Emmert, and J. H. Clark. 1998. Effects of source of carbohydrate and protein and rumen-protected methionine on performance of cows. J. Dairy Sci. 81:221-228.

Polan, C. E., K. A. Cummins, C. J. Sniffen, T. V. Muscato, J. L. Vicini, B. A. Crooker, J. H. Clark, D. G. Johnson, D. E. Otterby, B. Guillaume, L. D. Muller, G. A. Varga, R. A. Murray, and S. B. Peirce-Sandner. 1991. Responses of dairy cows to supplemental rumen-protected forms of methionine and lysine. J. Dairy Sci. 74:2997-3013.

SAS User's Guide: Stastic, Release. 7th ed. 1998. SAS Institute, Inc., Cary, NC.

Schingoethe, D. J., D. P. Casper, C. Yang, D. J. Illg, J. L. Sommerfeldt, and C. R. Mueller. 1988. Lactational response to soybean meal, heated soybean meal, and extruded soybeans with ruminally protected methionine. J. Dairy Sci. 71:173-180.

Suckhija, P. S., and D. L. Palmquist. 1988. Rapid method for determination of total fatty acid content and composition of feedstuffs and feces. J. Agric. Food Chem. 36:1202-1206.

Valadares, R. F. D., G. A. Broderick, S. C. Valadares Filho, and M. K. Clayton. 1999. Effect of replacing alfalfa silage with high moisture corn on ruminal protein synthesis estimated from excretion of total purine derivatives. J. Dairy Sci. 82:2686-2696.

Van Horn, H. H., A. C. Wilkie, W. J. Powers, and R. A. Nordstedt. 1994. Components of dairy manure management systems. J. Dairy Sci. 77:2008-2030.

Van Soest, P. J., J. B. Robertson, and B. A. Lewis. 1991. Methods for dietary fiber, neutral detergent fiber, and nonstarch polysaccharides in relation to animal nutrition. J. Dairy Sci. 74:35833597.

Yang, C. M. J., D. J. Schingoethe, and D. P. Casper. 1986. Protected methionine and heat-treated soybean meal for high producing dairy cows. J. Dairy Sci. 69:2348-2357.

Zimmerman, C. A., A. H. Rakes, T. E. Daniel, and B. A. Hopkins, Jr. 1992a. Effect of total and rumen undegradable protein on the performance of cows fed low fiber diets. J. Dairy Sci. 75:19541964.

Zimmerman, C. A., A. H. Rakes, T. E. Daniel, and B. A. Hopkins, Jr. 1992b. Influence of dietary protein and supplemental niacin on lactational performance of cows fed normal and low fiber diets. J. Dairy Sci. 75:1965-1978.

Zimmerman, C. A., A. H. Rakes, R. D. Jaquette, B. A. Hopkins, Jr., and W. J. Croom, 1991. Effects of protein level and forage source on milk production and composition in early lactation dairy cows. J. Dairy Sci. 74:980-990. 